\title{
Repercussões psíquicas do (des)encontro traumático em tempos primordiais: um estudo de caso
}

\author{
Psychic repercussions of the traumatic (dis)encounter \\ in primordial times: a case study
}

\section{Bruna Bomfiglio Weber}

Resumo: $O$ presente artigo propõe uma discussão, a partir de um estudo de caso clínico, acerca do singular processo de constituição do Eu atravessado pelo (des)encontro traumático com um outro primordial. Objetivou-se compreender as repercussões psíquicas de experiências excessivas de dor que se presentificam na vida atual da paciente em questão. À luz da teoria psicanalítica, explorouse as complexidades da constituição psíquica frente as vivências de indiferença e desamparo em tempos primordiais. Muito mais do que delimitar nomeações que rotulem, o intuito deste artigo é suscitar reflexões voltadas ao alcance da relação com o objeto quando se trata de um psiquismo marcado pela lógica da indiferença e do desamparo.

Palavras-chaves: Psicanálise; Constituição psíquica; Indiferença; Trauma.

\begin{abstract}
The present article proposes a discussion based on a clinical case study about the singular process of constitution of the self, matched by the traumatic (dis)encounter with the other primordial. The objective was to understand the psychic repercussions of excessive pain experiences that present themselves in the current life of the patient in question. Under the light of psychoanalytic theory, the complexities of psychic constitution were explored in the face of the attempts of indifference and helplessness in primordial times. Much more than delimiting appointments that label the subject, the purpose of this article is to raise reflections that aim at reaching the relationship with the object when it comes to a psyche marked by the logic of indifference and helplessness.
\end{abstract}

Keywords: Psychoanalysis; Psychic constitution; Indifference; Trauma.

1 Acadêmica do curso de psicologia da PUC/RS. E-mail: brunaweber1@gmail.com . 


\section{Introdução}

Desde que somos concebidos no mundo, na cena do nascimento, 0 sujeito é colocado frente a outro - o qual adquire inconcebível valor na posição de apresentar (e significar) esse ser ao mundo. Neste tempo primordial, a vivência do encontro com o outro tem um valor significativamente único para o processo de constituição psíquica e seus efeitos à posteriori (Moraes \& Macedo, 2011). Logo, para emergir um sujeito psíquico, há de existir necessariamente a presença do outro.

Compreendendo o Eu como algo que não está presente desde o início, é necessário que ele seja desenvolvido. Essa construção demanda a existência de outro, que tenha a capacidade de investir libidinalmente em um corpo que, inicialmente, clama respostas de ordem autoconservativas. Ao demandar ao outro um seio que supra suas necessidades biológicas, 0 bebê recebe algo que extrapola a condição biológica, indo ao encontro de um "seio desejante, historizante e historiado" (Hornstein, 2008, p. 28), instaurando, então, uma marca pulsional no psiquismo do sujeito. Portanto, para o bebê reconhecer-se como diferente do outro, deve haver a saída de seu estado autoerótico - estado anterior à possibilidade de representação que o indivíduo faz de si mesmo para uma nova fase do desenvolvimento libidinal: o narcisismo primário. Uma nova ação psíquica, proveniente dos objetos primordiais, precisa encontrar-se com 0 autoerotismo, disponibilizando, assim, condições necessárias para 0 surgimento de uma imagem unificada do Eu. Por fim, é por meio dessa ação específica que o sujeito adquire uma representação psíquica de sua própria superfície corporal (Santos, 2007).

Há uma inegável importância do papel dos objetos primordiais nas inscrições que fundam a estrutura psíquica de um sujeito. Esse outro primordial, através de uma sensível experiência, terá de captar, intuir e compreender a demanda de seu filho. As expressões visíveis do corpo do bebê irão oportunizar, assim, experiências que complexizem esse aparelho psíquico. Para que isso ocorra, Kehl (2004, p. 44) aborda que "antes mesmo de nascer, 0 bebê deva representar na fantasia dos pais, a possibilidade de realização dos ideais infantis de perfeição narcísica aos quais estes tiveram de renunciar". Logo, é através do bebê que os pais reatualizam seus ideais de eu. Assim, proporcionam ao filho um investimento imperado por ilusões narcisistas, potencializando 0 surgimento do narcisismo infantil. Bleichmar (2005) afirma que é a capacidade de voltar-se para o bebê como sujeito outro, capacidade nomeada de narcisismo transvazante, que é fundada a sexualidade no infans. É pela via narcísica transvazante que irá existir a possibilidade de que, em tempos posteriores, haja a capacidade de amor de objeto, visto que esses objetos primordiais tiveram a capacidade de investir amorosamente nesse outro de forma alteritária. Deste modo, só é possível a criança reconhecer-se como um Eu distinto por meio do investimento libidinal de seus objetos primordiais, considerando-0 um outro de alteridade (Macedo, 2015).

Há uma vasta gama de desdobramentos possíveis relacionados aos encontros inaugurais do bebê e seus objetos primordiais. Como discorrido anteriormente, quando esses objetos são capazes de ligar-se afetivamente a essa criança, criando condições de cuidado, abrem-se vias para a etapa narcísica do desenvolvimento. Nesse momento, é construída a possibilidade do sujeito reconhecer-se distinto do outro (Moraes \& Macedo, 2011). Entretanto, faz-se necessário enfatizar que a construção de uma imagem unificada do Eu nem sempre será desenvolvida de forma esperada, pois, para que haja 0 egresso de um estado para outro, é necessário que o ambiente seja facilitador desse processo. Bleichmar (1994) outorga o papel do outro primordial por meio da concepção de duplo comutador, ou seja, ao mesmo tempo em que esse objeto excita 0 bebê e deposita a sua própria sexualidade nele, também Ihe fornece elementos que suscitem a ligação dessas excitações. Dessa forma, concede 0 instaurar das pulsões e o processo de narcisização do sujeito. Esse outro transmite mensagens enigmáticas que agita sua cria e, ao mesmo tempo, tem subsídios representacionais egóico-narcisistas que concede um olhar ao bebê de forma unificada. Nesse sentido, Bleichmar (1994, p. 26) coloca que "a libido desligada, intrusiva, que penetra, será ligada inicialmente por vias colaterais, mediante este narcisismo estruturante que um vínculo amoroso propicia". Portanto, o objeto terá de fornecer um aparato narcísico para que possam ser ligadas essas excitações que ele mesmo depositou na criança. Caso contrário, poderão ser geradas importantes intensidades psíquicas, designando que a criança permaneça rendida às excitações não representadas. Isso submeterá o infans a uma dor incessante. Devido a impossibilidade de inscrição e ligação dessa intensidade, ela irá repetir-se compulsivamente, instaurando um circuito de excitações que não conseguiram ser evacuadas no psiquismo do bebê (Belo, 2004).

Nesse sentido, evidencia-se a pertinência em abordar a compreensão do traumático e seus efeitos no psiquismo do sujeito. As experiências traumáticas presentificam-se desde os momentos primordiais de constituição do psiquismo, sendo inerentes a esse período. Quando o outro - sujeito de sexualidade - instaura a pulsionalidade na criança, ele remete, junto à inauguração do sexual, o trauma. Esse trauma inaugural fará com que o psiquismo da criança se movimente em busca do encontro de novas vias, permitindo a tradução desses influxos que recebe, como forma de escoar a energia quantitativa. Freud havia colocado esse processo como verdadeiro motor da vida psíquica, pois, frente a essa energia não ligada, vê-se obrigado a encontrar novas vias psíquicas (Bleichmar, 2005). Todavia, se o sujeito não aufere vias representacionais para significar a experiência, é atestado um fracasso na metabolização da energia, na condição de simbolizar. Logo, instaura-se um potencial campo, para um destino que o sujeito, possivelmente, fique capturado pela compulsão à repetição, gerando impasses em sua economia psíquica no decorrer de seu desenvolvimento libidinal (Filho, 2011). Portanto, pode-se considerar traumático aquilo que não circula de maneira habitual pelo aparelho psíquico. As experiências que podem suscitar uma ordem traumática vão de encontro, em tempos primórdios, com o (des)encontro entre o bebê e 0 outro que atende às suas necessidades psíquicas vitais. Essa experiência de excesso deixa uma marca que não está no campo representacional, mas no campo da intensidade experienciada (Moraes \& Macedo, 2011).

Dessa forma, considerando a complexidade do processo de constituição psíquica, é de grande importância dar luz aos efeitos de experiências que excedem a capacidade de metabolização do psiquismo nos encontros inaugurais do sujeito psíquico. No entanto, essas experiências podem extrapolar o traumático constitutivo, adentrando no terreno do irrepresentável. Desse modo, a partir do caso da paciente, serão abordados os efeitos das marcas do não reconhecimento de seu existir em sua história e de como se desenvolvem suas relaçōes com os objetos externos, através da lógica da reprodução das intensidades atordoantes que foram experienciadas em um tempo primitivo. Para isso, também serão trabalhados ao longo deste artigo os conceitos de indiferença e desamparo, considerados disparadores para a compreensão dos modos de relações primordiais traumáticos. 


\section{Metodologia}

0 presente artigo foi construído por meio do estudo de caso de uma paciente de 26 anos, do sexo feminino, nomeada no decorrer do estudo por Amália. A paciente fora encaminhada para atendimento na clínica de uma instituição psicanalítica na região metropolitana do sul do País.

Os atendimentos clínicos do estágio na referida instituição têm duração de 50 minutos, sendo a frequência semanal estabelecida após os encontros iniciais. As primeiras entrevistas acontecem antes do estabelecimento do contrato e tem como intuito que paciente e terapeuta se conheçam, para que possam construir a demanda do tratamento de forma conjunta. Nesse momento inicial, a construção da demanda de tratamento partirá da queixa do paciente, o sofrimento que incitou a busca por terapia e que propulsiona 0 desejo de mudança em sua vida. Cabe ao terapeuta auxiliar na busca do que não é manifesto, do desconhecido, do que está latente e não nomeado: 0 inconsciente (Silva, 2008).

A prática do terapeuta-estagiário com a escuta analítica vai além das quatro paredes do setting. Todas as sessões são relatadas em dialogadas e supervisionadas por um psicanalista. A supervisão se dá a partir do relato do estagiário acerca do caso, sendo trabalhadas questões referentes à técnica e metodologia psicanalítica. Como explicita Tizio (2003, p. 57), a supervisão é um espaço no qual propicia "fazer funcionar as orelhas, não para ouvir, mas sim para fazer localizar aquilo que deve ser ouvido". Portanto, é no espaço de supervisão que a escuta pode ser potencializada e afinada, para que se escute aquém do que está posto no manifesto, dando voz ao que está latente e recalcado.

Compreendendo a importância da escuta da singularidade da paciente, este artigo tem como objetivo a compreensão do papel dos objetos primordiais frente ao processo constitutivo do psiquismo de Amália e dos atravessamentos traumáticos de seus encontros primordiais, bem como evidenciar as repercussões destes em seu atual modo de relação com o mundo. Portanto, o intuito dessa produção é proporcionar reflexões e questionamentos acerca de hipóteses do campo estrutural e funcional de Amália. Pretende-se não proporcionar um olhar que possa rotular a paciente - o qual poderia ser uma repetição da violência que a mesma sofrera em tempos primórdios. Limites éticos de anonimato e sigilo foram cuidadosamente respeitados.

\section{Resultado e discussões}

Amália chegou à instituição em meados de janeiro de 2019, provinda de um encaminhamento pela rede de saúde pública. Seu primeiro contato com a escuta analítica se deu através da clínica de formação em al guns encontros iniciais. Nesse primeiro momento, seu sofrimento foi escutado e foram refletidas as possibilidades de tratamento da paciente, visto que a mesma verbalizava estar passando por um momento de dificuldades financeiras, sem condições para investir em uma análise. Levando em conta 0 atravessamento financeiro e o sofrimento de Amália, foi concluído de que a mesma se beneficiaria de um encaminhamento para a clínica do estágio da instituição.

Meu primeiro encontro com a paciente se deu dia 8 de fevereiro de 2019, algumas semanas após 0 encaminhamento. Logo de início, Amália se apresentou a partir de seu diagnóstico de depressão e pontuou fazer uso de medicações psiquiátricas há mais de 12 anos. Segundo a paciente, estas teriam como objetivo: "Fazer efeito nas coisas que eu sinto, porque eles me acalmam, não deixam eu ter de novo uma crise depressiva. Mas eu sempre sei que os sentimentos de tristeza ainda estão ali identro" (sic). Amália relatou que sua procura pela instituição analítica ocorreu devido a redução da efetividade das medicações em conter seus afetos depressivos, sentindo-se transbordar emocionalmente desde que sua mãe falecera, há cerca de 1 ano. A paciente também se designou como uma pessoa de poucos amigos, descrevendo-se como muito sensível e difícil de conviver - afirmou, também, ser descrita dessa forma por seu limitado ciclo social. Amália referiu ter sofrido graves experiências de abuso e agressão, bem como presenciado o intenso uso de drogas dos pais dependentes químicos. Nesse primeiro momento, foi escutado o que era manifesto no discurso de Amália, entretanto, através do que se colocava latente em sua narrativa que foram compreendidas as vias nas quais seus afetos circulavam. Além disso, foi perceptível a posição em que a mesma colocava-se frente ao outro - posição esta de grande importância para compreensão de seu funcionamento.

É também importante situar o que circula psiquicamente em um início de tratamento, pois, ao compreender os mecanismos que estão em jogo neste início, puderam ser observados alguns traços importantes de Amália, evidenciando um psiquismo mais fragilizado. Assim sendo, o início de um tratamento se dá pela motivação a serviço de vida - a qual leva o paciente à terapia. No entanto, como coloca Silva (2008, p. 39): "acompanhadas pelo desejo de buscar a significação do incompreensível que se encontra no inconsciente vêm as resistênciass". Da mesma forma que há um sofrimento que fizera com que a paciente desejasse adentrar em um processo terapêutico, também há um contra-investimento atuando, para que 0 Eu se proteja de materiais indesejáveis provindos do inconsciente. Essas resistências irão sempre estar presentes, entretanto, entende-se que por ser o início de um tratamento, elas estarão atuando de forma mais intensa, visto que as energias necessárias para superá-las ainda não foram trabalhadas. É esperado, a partir disso, que nesses primeiros encontros o discurso manifesto do paciente seja cauteloso, não adentrando diretamente às conflitivas nas quais repercutem seu sofrimento atual. Como referido anteriormente, as resistências estarão atuando mais vigorosamente nesse momento para não haver um contato do Eu com as representações conflitivas, visto que isso levaria a um aumento de tensão no aparelho psíquico (Freud, 1937). Contudo, Amália, nesse primeiro encontro narrou vivências de sua história, as nomendo, em suas próprias palavras, como traumáticas, como referido em sua narrativa:

Eu fui em busca da terapia em decorrência dos traumas que tenho relacionados aos meus pais... [...] Frequentemente, algumas cenas de meus pais usando drogas na minha frente vem em meus pensamentos, eles separando em cima de um prato para usar. Eu via minha mãe se contorcendo no chão quando usava muito (sic).

Assim, como outros relatos explíitos acerca das cenas de abuso sexual que viveu e tentativas de suicídio que presenciou, cenas estas permeadas por extrema violência. A partir dessas narrativas e do excesso traumático evidenciado nas vivências infantis de Amália, faz-se questionar, nesse primeiro momento, sobre a possibilidade de uma constituição psíquica com falhas importantes. Essas falhas corresponderiam, assim, a fragilidade em suas barreiras (as quais trabalhariam a serviço das resistências) no material trazido na primeira sessão. Então, a mesmo tempo em que há uma tentativa de proteção - tentativa colocada na articulação da defesa referida - há, 
também, um transbordamento desse sofrimento. Entretanto, mesmo com a evidente fragilidade psíquica, Amália demonstrou ter recursos para investir em atividades diárias que marcavam seu aspecto saudável e funcional, como no trabalho e em seus estudos universitários. De qualquer maneira, os registros dessas vivências primárias ainda repercutem atualmente em Amália, por via dos seus investimentos libidinais e suas vivências no campo da intersubjetividade.

\section{Relações primárias e constituição psíquica}

Compreendendo que o tempo inaugural da sexualidade do bebê ocorre através do ato do cuidado e da resolução da tensão interna provinda do campo da necessidade, colocam-se em questão as características nas quais esse encontro primordial se apresenta. A qualidade das vivências primárias com o outro é de sumo valor, pois, dependendo da forma na qual essa relação ocorre, destinos traumáticos podem estar presentes no nível constitutivo do Eu. Para Amália, a qualidade de suas relações primordiais foi permeada pelo caráter tanático do investimento de seus pais nela. Quando não era deixada sozinha, o convívio com seus objetos se dava através da violência da vivência de indiferença. Sendo esta caracterizada por Moraes e Macedo (2011), como o modo de encontro psíquico onde o bebê não encontra em seus objetos condições de consideração e percepção, necessários para a representação da assimetria presente na relação. Logo, o investimento afetivo, que induziria a um trabalho de interpretação e ligação das intensidades que ameaçam a criança internamente, é deficitário nesse cenário. A indiferença impede que seja apresentada a diferença - a qual marca o encontro alteritário - para o bebê.

No decorrer dos atendimentos, Amália reiterou a condição de seus pais de abuso de substâncias ilícitas e colocou que a gravidez de sua mãe não fora planejada. 0 fato inesperado dessa gravidez, afirmou ela, não fora um dispositivo que se atravessara no desejo de sua mãe sobre ela como filha. Todavia, a narrativa de Amália sobre sua história evidenciará um desejo de seus pais em outro campo, distinto do desejo a serviço do amor. Muitas vezes, em circunstância do uso de drogas, os pais de Amália encontravam-se fora de casa, normalmente para encontrarem-se com grupo de amigos para usar crack. Essas saídas recorrentes dessas figuras expunham-na a situações de vulnerabilidade, pois, muitas vezes, estes a deixavam sozinha, sem um cuidador. Entretanto, é importante ressaltar que mesmo que existisse a presença física dos pais junto a ela, essa presença era, por vezes, uma presença-ausente. Essa característica vai ao encontro do que colocávamos anteriormente sobre as peculiaridades do encontro da criança com seus objetos primordiais marcado pela indiferença.

Ao ser retirado, em tempos primórdios, seu direito de sujeito de desejo, de diferenças como outro, seu processo de constituição psíquica ficara marcado pela violência do não reconhecimento de si. Dessa forma, vindo a repercutir em tempos posteriores nas tentativas de Amália de relacionar-se com 0 outro em seu âmbito social. Em suas narrativas sempre foi muito explícito a condição de indiferença e desalento que permearam suas relações primárias, como é colocado - de forma muito emotiva - em seu relato na oitava sessão:

Eu não fui cuidada quando eu era criança, porque nem minha mãe, nem meu pai me davam carinho e cuidado. Eu lembro que eu tinha que chorar muito para chamar a atenção da minha mãe. Às vezes era difícil, porque ela estava drogada ou fazendo outras coisas que não podia me dar atenção, então eu tinha que tentar me virar sozinha, mas não conseguia (sic).

Esegue:

Quando eu dormia no quarto com minha mãe e meu pai, às vezes eu via eles tendo relações. No início eu pensava que eles estavam brigando, discutindo, se batendo e eu ficava com muito medo. Muitas vezes fingia que estava dormindo para não acontecer a mesma coisa comigo, porque eu tinha medo que ele me batesse também. Mas depois eu comecei a entender que na verdade eles não estavam se batendo, eles estavam tendo relações... (sic).

Essas cenas referidas pela paciente salientam dois tempos marcados pelo excesso traumático. Podemos pensar que a primeira cena pode ligar-se à uma vivência de traumatismo primário, sendo evidenciado o desamparo frente às suas necessidades conservativas (biológicas e psíquicas). Já a segunda cena nos remete a um segundo tempo do trauma, onde a experiência de presenciar seus pais tendo relações sexuais em sua frente repercutiu em uma intensidade que não era passível de ser representada. Isto se deu devido às fal has anteriores no processo de constituição psíquica, as quais foram constituídas no tempo do trauma primário, repercutindo em um empobrecimento dos recursos psíquicos e impossibilitando a metabolização da energia.

Essas vivências referidas se situam no campo do excesso, onde as intensidades que ingressam no aparelho psíquico fogem da capacidade de simbolização e ligação à uma representação. Diferente do que foi citado anteriormente, onde o papel do outro frente a o bebê seria o de cuidado, de afeto, de resposta ao desamparo, o que se evidencia nas vivências relatadas por Amália foi 0 oposto a isso. Os pais da paciente mostravam não possuir recursos para manter uma capacidade de ligação afetiva em relação a ela, deixando-a ocupar o lugar de desamparo próprio desse tempo inaugural (Moraes \& Macedo, 2011). A incapacidade dos pais de Amália de tomarem uma posição parental esperada, também estava atravessada pelas repercussões psíquicas de suas próprias histórias familiares, impossibilitando que estes estivessem no papel que propiciasse à Amália um ambiente saudável para seu desenvolvimento.

Ao contrário do ritmo constituinte, em que o hiato entre a ausência e presença do outro tem potência criadora para inscrições de novas representações e significações de si no psiquismo do bebê, os encontros de Amália eram descompassados. Esse ritmo desregulado suscitou o predomínio da angústia frente à possibilidade de perda desse objeto quando ele não estava junto a ela, visto que esse outro nunca dera subsídio para Amália sentir-se segura de que este retornaria após o período de sua ausência. Dessa forma, percebe-se seu relato tomado por angústia ao discorrer sobre as ausências da mãe:

Às vezes ela desaparecia por dias, e eu não sabia se ela ia voltar ou não. Eu ficava muito mal com isso, por não saber se ela tava viva ou morta. Então eu tinha que esperar e isso me devastava, eu ficava muito mal. Sem contar quando eu era bem 
menor e ela me trancava dentro de casa, sem eu saber cozinhar e fazer nada, e muitas vezes dormia fora e só chegava no meio dia do dia seguinte. E ainda quando eu ia pedir pra ela fazer alguma coisa pra comer ou tentar ficar com ela, ela me xingava, falando que tava cansada e que ia dormir. Eu lembro disso e fico me perguntando: que mãe que faz isso com a filha?! Não se faz isso. Sem contar que nessas vezes que ela me trancava ela me dava remédio pra eu dormir, só que às vezes ela me dava uma dose mais baixa e eu acordava no meio da noite, sem ninguém perto e daí eu tinha que tentar voltar a dormir pra passar mais rápido esses momentos. Às vezes eu fico lembrando disso... E pensei muito nisso nessa semana (sic).

Nessa mesma sessão, a paciente retoma vivências tidas no mesmo campo com seu pai, o qual desaparecia por meses devido ao seu vício de drogas, ficando na rua por longo período sem retornar para casa. Como consequência dessa instabilidade entre presença-ausência, o processo de reconhecer-se como um Eu íntegro, diferenciado de seus objetos, foi debilitado no desenvolvimento psíquico de Amália. Logo, pôde-se evidenciar um deficit no tempo primordial de Amália (em seu caminho de autonomia psíquica), em que seus objetos apresentaram uma falta frente à presença-ausência constituinte, delegando a esta seu direito infantil de existir, não investindo em sua filha afeto da ordem alteritária, de amor. Frente a impossibilidade dos objetos em amar, Amália não fora colocada em uma ordem simbólica - que fundaria o psiquismo representacional (Dockhorn, Macedo \&Werlang, 2007). Éimportante enfatizar que, embora os pais da paciente assumissem uma posição permeada pela violência e indiferença, eles ainda se mostravam presentes. Mesmo que sua relação com essas figuras fora precária, seus pais não se imprimiam de forma totalmente ausentes. A mínima presença proporcionou à Amália subsídios para constituir-se psiquicamente, mesmo que de maneira muito frágil, evitando 0 estabelecimento de uma estrutura psicótica.

\section{Trauma, estrutura e repercussões atuais}

Como colocado anteriormente, Amália vivenciou sua infância em um ambiente permeado por elementos mortíferos. Sua relação com os objetos primários foi tida no campo do desamparo, deixando seu psiquismo à mercê de intensidades que escaparam do circuito representacional e de metabolização. Essas catexias não ligadas em seu psiquismo marcam vivências tidas no campo do trauma. Conforme aborda Freud (1920/1977), este se determina quando há irrupção de uma barreira protetora das capacidades defensivas do aparelho psíquico, por meio de uma experiência dramaticamente descompassada em torno da possibilidade de processamento de quantidades, irrompendo o sistema representacional. Como bem colocam Moraes e Macedo (2011, p. 42)"0 acontecimento, com sua intensidade, rompe o que seria da ordem do sensato, fraturando e arrancando do sujeito qualquer possibilidade de historicização do experienciado frente aos recursos então disponíveis".

A posição de indiferença apresentada pelos pais denúncia a marca do não reconhecimento do existir da criança, predominando o desmentido frente à existência desta como um outro de diferença (Birman, Fulgencio, Kupermann \& Cunha, 2016). Devido a seus parcos recursos, os pais de Amália colocavam-se em posição de sobrepor sua verdade no lugar da verdade da filha, assumindo uma posição perversa frente à condição de desamparo e dependência do bebê, desautorizando a expressão de suas necessidades. Essa condição de poder, assumida de maneira perversa por seus pais, outorga o desmentido nessa relação (Antoniazzi \& Weinmann, 2018).

Exposta a esse ambiente excessivo, somando a seus primitivos recursos psíquicos de mediação, Amália necessitou utilizar mecanismos defensivos que estavam ao seu alcance para proteger-se das experiências traumáticas frente a esse pacto mortífero com seus objetos primordiais, a clivagem. Roussilon (como citado em Monteiro \& Cardoso, 2016) fez uma interessante conceitualização acerca do mecanismo de clivagem em estruturas primitivas, enfatizando-0 não como um mecanismo defensivo do Eu (clivagem do eu) mas, sim, um mecanismo defensivo ao Eu (clivagem ao eu). Nas palavras das autoras Monteiro e Cardoso (2016, p. 81):

A menção a uma clivagem ao ego diz respeito à ruptura que ocorre na subjetividade frente ao traumatismo primário. 0 sujeito "corta"sua vida psíquica subjetiva, "retira"de si a impressão traumática. A subjetividade passa a estar dividida em uma parte representada e uma parte não representada.

Diferente do exposto por Freud acerca desse mecanismo nas psicoses e perversões, a divisão para 0 Eu que se constitui de maneira precária não se dá em duas cadeias representativas diferentes, mas, em uma ruptura na organização subjetiva. Assim, fica uma parte aquém da possibilidade de representação e que acaba por não se integrar ao Eu. Dessa forma, a defesa eleita passa a tornar a vivência traumática como um "episódio sem sujeito de experiência, em que a própria distinção entre externo e interno se anula" (Figueiredo, 2003, p. 19). Por fim, haverá a tentativa de retorno dessas partes clivadas, através dos reinvestimentos dos traços dessas experiências. Isto fará com que o psiquismo passe a funcionar sobre a égide da compulsão à repetição, atualizando o traumático outrora experienciado. Os efeitos dessa matriz reprodutiva dos impactos mortíferos proliferados no modo de ser e estar no mundo de Amália foram extremamente importantes para a compreensão das dinâmicas de seus investimentos, levando em consideração as relações em que se encontrava quando chegou à terapia.

Anterior aos relatos da paciente no que concerne suas vivências atuais, pautadas no campo da compulsão à repetição e seus efeitos tanáticos, é relevante fazermos uma compreensão mais objetiva acerca das repercussões psíquicas que norteiam seu modo de relacionar-se com o outro. Como referido anteriormente, o psiquismo de Amália, frente ao excesso traumático irrepresentável, necessitou utilizar de mecanismos (clivagem) que mantivessem 0 mínimo de estabilidade e apaziguamento para sua sobrevivência psíquica. Todavia, essa saída dramática afetou os limites entre as instâncias psíquicas e as fronteiras da interioridade e exterioridade. Como pontuam Mello e Herzog (2012, p. 76): "no lugar de uma construção de sólidos organizadores tópicos, dinâmicos e econômicos do funcionamento mental, conta-se com a fabricação de barreiras protetoras, simultaneamente, rígidas e frágeis". Nesse contexto, 0 Eu encontra-se em instabilidade, principalmente quando refere-se ao modo de relação com objeto, o qual fica sob domínio de um confuso e frágil limite entre corpo/psique, interno/externo (Mello \& Herzog, 2012). É interessante pensarmos também que o significante "frágil" não é atoa que se encontra tantas vezes redito nesse artigo: os objetos outros de Amália estiveram de 
certa forma presentes (qual forma que seja) em tempos primordiais, a ausência destes não era completa e, por isso, Amália não ficou totalmente à mercê de um corpo indiferenciado com o mundo que o cerca, o que seria considerado uma psicose. Por isso a veemência ao citar que as fronteiras psíquicas de Amália encontram-se presentes de certa forma, mesmo em medidas precárias e frágeis. Podemos pensar, então, que há resquícios de inscrições narcisistas, mesmo que permeadas por essas fragilidades psíquicas e transpassadas veementemente por pulsões mortíferas.

É possível refletirmos, também, sobre as vivências em tempos do desenvolvimento libidinal posterior - etapa narcísica, conflito edípico, entre outras etapas fundantes do sujeito de desejo -, serão experienciadas a partir do lugar frágil de Amália em tempos de constituição de uma representação de si. Logo, é evidente que Amália vivenciou suas etapas constitutivas posteriores permanentemente sob ameaça que a diferença dos outros impõe a si. Essa matriz de repetição mortífera que engendra suas relações - claramente fora do campo da alteridade - reina o estado de indiferença, visto que essa é a forma de Amália administrar seus investimentos: combatendo a constatação da diferença do campo alteritário (reproduzindo o que fora experienciado em tempos primórdios com seus objetos primordiais). Essa violência na tentativa de negar o outro como um diferente coloca sob a luz a precária capacidade de investir.

Como sublinham Birman e colaboradores (2016, p. 153), "esse prejuízo repetido atualiza as fraturas no processo de constituição narcísica, e evidencia, assim, a violência traumática que passa a reproduzir-se no campo alteritário, ou seja, no encontro entre o Eu e os objetos". Então, esses frágeis limites estabelecidos de diferenciação entre o Eu e o objeto evidenciam características próprias de uma parcialidade da pulsão que, como citado anteriormente, coloca Amália no campo de investimentos autoeróticos. As inscrições das vivências de indiferença condenaram o psiquismo de Amália a uma repetição do excesso experienciado em sua história pela via do ato, articulando as intensidades que não foram passíveis de simbolização. 0 ato, colocado como uma tentativa de reequilibrar a dinâmica psíquica, corresponde ao vigor do excesso e encontra em sua expressão singularidades que o ponham como expressão dessa dor psíquica, articulando uma performance de ato-dor (Moraes \& Macedo, 2011). Esta expressão é estritamente vinculada à memória da dor da indiferença e reproduz continuamente, através da descarga, a impressão do excesso experienciado, interceptando a possibilidade de metabolização psíquica dessa intensidade (Moraes \& Macedo, 2011).

Após vislumbrar o lugar que Amália ocupa atualmente na relação com 0 outro - mundo que a envolve -, o ilustrar dessas repetições na ordem da eleição de objetos amorosos faz sentido, visto que é nas relações de erotismo e ternura que os conflitos mostram-se mais evidentes. Dessarte, os namoros de Amália foram envoltos pela força mortífera de sua história vivida. Épertinente ressaltar que seus dois relacionamentos, por mais que se mostrassem inicialmente diferentes e opostos entre si, estavam sob o sustento da compulsão à repetição da pulsão mortífera que circula em seu psiquismo, aparecendo em ato na sua relação com o outro.

Para contemplar melhor a dinâmica de seus dois relacionamentos, são citados breves trechos de sua fala:

[...] e acho que até pode ter vindo daí a minha necessidade de ter alguém junto comigo, para conseguir suprir a falta da minha mãe... Porque eu tinha 15 anos nessa época e namorava o meu ex, que fiquei 7 anos, então como a minha mãe já nem morava mais comigo, ele acabou indo morar lá, porque ele ia me cuidar quando eu estava sozinha. Então ele meio que supriu essas faltas da minha mãe... ele cozinhava, me dava carinho, cuidava da casa, ajudava nas contas e quando eu ficava doente ele me levava no hospital. Então eu morei com ele todo esse tempo que ela tinha me deixado (sic).

E, relacionado ao seu último namoro:

Isso já aconteceu nas outras vezes que aconteceu agressão, mas eu não conseguia ver. Eu deveria ter terminado já na primeira vez, mas eu não consegui. Eu também não sei como me coloquei naquela posição de aceitar tudo que ele fazia comigo, eu sou uma idiota mesmo, perdi tanto tempo do lado dele. Ele me manipulava em tudo... Como que eu não vi isso?! [...] Ele me controlava a todo o momento, sempre ia comigo nos lugares, decidia o que nós íamos fazer, comer, qual filme a gente iria ver, que amigos eu podia ter... Exatamente tudo (sic).

O segundo relato foi trazido na sexta sessão, na qual circulava no setting o transbordamento emocional dos excessos traumáticos experienciados em cenas de agressões físicas sobre seu corpo e abusos psicológicos. 0 questionamento "Como que eu não vi isso?" abarca a força cega dessa pulsão mortífera, não encontrando vias para se significar e, por isso, é escoada através do ato, da repetição das forças tanáticas em tempos atuais de maneira silenciosa.

No relato de Amália referente à sua primeira relação, é possível visualizar as frágeis barreiras que estavam estabelecidas entre ela e seu namorado, evidenciando uma confusão do lugar de si e do outro. 0 desamparo primário estava inscrito em sua relação, quando elegeu um sujeito que estivesse em uma posição de suprir suas necessidades mais básicas e primordiais, quase de uma ordem autoconservativa. Portanto, o ex namorado de Amália não estava colocado como um objeto de desejo erótico e genital, visto que a paciente ainda se encontra em tempos anteriores do desejar alguém como um outro distinto de si. Amália encontrava-se fusionada com seu ex namorado, sendo ele eleito como objeto que assumisse uma ordem nas adicções (no campo das relações amorosas), sendo um rebatimento do desejo sobre a necessidade. Aulagnier (como citado em Cardoso, 2005, p. 69) afirma que as toxicomanias relacionadas à paixão amorosa se tratam de "uma relação na qual o objeto tornou-se para o Eu de um outro fonte exclusiva de todo o prazer, e foi por ele deslocada para o registro da necessidade". Já em sua segunda e última relação, o caráter mortífero mostrou-se de forma mais crua ao eleger um objeto no qual a colocava em uma posição de abuso. A relação de necessidade também perpassava no relacionamento, mas uma necessidade muito mais vinculada às vias tanáticas do que propriamente de Eros. Amália sofria vários abusos, tanto físicos, quanto verbais que refletiam em seu sofrimento psíquico.

Além da visível repetição da matriz de indiferença, em suas tentativas de relação com objeto outro de forma alteritária, foi presentificado uma 
posição que estava presente a todo o momento de novas ligações com 0 outro: posição de abuso. Suas escolhas objetais se davam em uma eleição de objeto a partir de sua condição de ser violentada - tanto na repetição da matriz da indiferença, quanto nas reatualizações dos abusos físicos - e de se colocar em um lugar de culpabilidade (sentimento este que ultrapassava o campo das relações amorosas). Nesse termo, podemos pensar um modo de funcionamento também transpassado pela dor-prazer: o masoquismo. É interessante contextualizarmos o caminho no qual a pulsão agressiva voltada ao Eu - o que caracterizaria o masoquismo - tramita, pois clarificará o modo de funcionamento da paciente frente a essa condição de satisfação tão peculiar. Entre os quatro destinos pulsionais que Freud aborda (recalcamento, sublimação, transformação no contrário e retorno para si mesmo) o que prevalece na dinâmica sadismo-masoquismo é o retorno da pulsão para si mesmo. Nesse destino pulsional referido, há uma troca do objeto que receberá a meta da pulsão agressiva, tornando o Eu como receptor do sadismo que antes era destinado ao outro, caracterizando, então, o masoquismo erógeno - que passa a acompanhar a libido em todas as fases do desenvolvimento (Conte, 2002). Nesse sentido, é possível pensar que no desenvolvimento psíquico de Amália, as pulsões agressivas destinadas aos seus pais poderiam ser insustentáveis ao Eu fragilizado desta, visto que eram suas únicas referências de um mínimo cuidado. A raiva poderia levar a destruição desses objetos e, por isso, essas pulsões tenderam a retornar ao seu Eu. Entretanto, devido aos precários limites entre Eu-outro, o retorno das agressões a si também era uma forma de atingir esses objetos, visto que a separação destes se dava de forma tênue. É importante ressaltar que a dor imposta no funcionamento do masoquismo se coloca também como prazer, visto que ambas ocorrem na mesma tópica psíquica, impossibilitando a inscrição da barreira que delimita que o desprazer para um sistema seja prazer para o outro, pois ambos encontram-se juntos no mesmo local (Conte, 2002). Isto evidencia a paralisação no princípio do prazer, sendo o masoquismo uma expressão da pulsão de morte (Conte, 2002).

Retornando ao que fora referido sobre a posição de abuso que Amália colocava-se em sua última relação, podemos refletir os desdobramentos ainda no campo do masoquismo, entretanto não mais no campo erógeno e sim no moral. Para Conte (2002, p. 67):

[...] nessa forma de masoquismo, a condição de sofrimento infligida pela pessoa amada deixa de ser importante, o sofrimento é o que importa, pois o verdadeiro masoquista oferece sua face todas as vezes que se apresenta a oportunidade de receber um tapa.

A submissão de Amália frente às relações de abusos, também perpassa pelo sentimento inconsciente de culpa e pela necessidade de castigo que transita em seu psiquismo. O sentimento inconsciente de culpa coloca o sujeito em posição de vítima frente ao mundo, delegando aos outros os motivos pelos de seus lamentos e suas insatisfações com a vida, não se colocando como sujeito parte da cena e potente de retirar-se da situação em que estava reatualizando violências primárias (Laplanche \& Pontalis, 2016). Amália, em grande parte das sessões, trouxe em seu discurso (às vezes em nível manifesto, outras vezes latente) a culpabilidade de ser quem é. Ao colocar-se em relações abusivas, perpetuava essa posição da qual não poderia desvencilhar-se, pois esse era o modo pelo qual perenizava as violências vividas em sua história, sob o comando da compulsão à repetição.

Em tempo anterior à morte da mãe de Amália, suas decisões e escolhas de vida estavam sob império do desejo de sua mãe, como em sua escolha de curso da faculdade, profissão e até 0 ato de se dedicar aos cuidados da mãe em tempo integral. Nesse sentido, Amália conferia à sua mãe uma figura de grande idealização e identificação, mesmo com o papel falho que esta desempenhou, bem como atribuía a ela título de cumplicidade extrema. Nesse sentido, como coloca Lazzarini e Viana (2010, p. 276), nos sujeitos narcísicos:

[...] há uma forte relação de dependência com a mãe, dependência ambivalente, que são deslocados para todos outros objetos. 0 recuo para o mundo interno pode ser uma das tentativas de lidar com essa dependência, ou seja, o afastamento pode ser uma função reguladora que serviria como salvaguarda da identidade: uma forma de a proteção contra uma ameaça de invasão do eu e a subsequente ameaça de desintegração.

Essa idealização apresentou-se de forma recorrente no discurso da paciente, principalmente nas sessões iniciais, colocando-a como único objeto afetivo e amoroso de referência em sua vida. Frente à morte de sua referência materna, Amália se encontrou em um lugar no qual nunca havia habitado: 0 de se deparar com a possibilidade de novos investimentos, provenientes do seu próprio desejo, visto que perdera o objeto que guiava seu modo de estar no mundo. Esse momento de desnorteamento é colocado na décima terceira sessão:

Porque as minhas escolhas sempre eram pra dar orgulho pra minha mãe, principalmente a pedagogia, e agora que perdi essa referência eu não sei mais, eu me sinto meio perdida... [...] Várias coisas que não ando conseguindo fazer mais, porque antes a grande parte das atividades que eu fazia era pra minha mãe, se não era cuidando dela, era pra ela ter orgulho de mim, como a minha escolha por pedagogia, o trabalho nas escolas... E agora eu não to vendo mais sentido fazer essas coisas se ela não tá aqui (sic).

Além do impacto na paciente ao encontrar-se"sem referência" para arcar com sua própria posição frente ao mundo - visto que esse lugar não pôde ser alcançado em sua etapa narcísica infantil -, Amália encontrava-se em um processo de luto. Luto este que podemos questionar qual seria o objeto que perdera: uma parte de seu Eu - visto que seu limite entre si e o outro é precário - ou um objeto de investimento amorosos distinto de si?

\section{A palavra como via criativa do processo de (re)construção de si}

Assim como 0 Eu não está posto desde o início da vida, este também não estará pleno em algum momento. 0 sujeito sempre está frente a possíveis novas identificações, novos ideais e mudanças externas que o colocam frente à necessidade de conduzir a mudanças internas. Assim, a Psicanálise se apresenta como um caminho possível dessas mudanças, proporcionando que o sujeito encontre novas vias possíveis de circulação das intensidades que 
não foram metabolizadas e que estão no campo da repetição. Logo, como sublinha Bleichmar (1994, p. 61): "0 que não é possível de ser historizável deverá encontrar um modo de ligação e de ressimbolização se pretendermos que o objeto não fique sempre entregue à compulsão de repetição, quer dizer, ao exercício da pulsão de morte". O que Bleichmar (1994) coloca como "modo de ligação" enlaça-se com a potência criadora da palavra. É no processo terapêutico que se abrem vias possíveis para a criação de uma nova narrativa sobre si, podendo ser inscrito no psiquismo de Amália uma nova posição frente ao mundo, sobrepondo o caráter tanático do ato pelo simbólico da palavra. Essa potencialidade narrativa coloca o sujeito frente a um movimento de reterritorialização do que foi vivido, ao destinar a experiência para um lugar outro que permita ser produzido um sentido e uma (re)significação (Kegler \& Macedo, 2016). Essa experiência singular coloca o sujeito frente à possibilidade de subjetivar-se por vias da criação de sua própria história, isto é, transmitindo uma experiência sob novas formas, recriando-a e dando voz àquela experiência muda que se perpetuava sob domínio da repetição em ato. Como colocam Kegler e Macedo (2016, para. 32)"nas circunstâncias em que há testemunho, há, também, escuta. A dimensão de alteridade configura-se como uma expansão da esfera do dizer-se". Nesse sentido, é no encontro da escuta com o que fora enunciado, que se inicia um novo movimento psíquico de integrar o que estava alheio a si, o que estava fora da cadeia representacional, assim como um novo lugar frente ao outro começa a surgir: o lugar de alteridade.

Tendo 0 trauma como intensidade que paralisa e impede a circulação psíquica da experiência, é na palavra que surge a possibilidade do sujeito de revisitar o passado para compor no presente uma narrativa que abra espaço para o devir de ser sujeito de si, devir este que sublinha uma história viva que abarca todas as possibilidades de sentido de ser (Kegler \& Macedo, 2016). Assim, Amália estreia seu protagonismo no devir que é ser sujeito não assujeitado ao que viveu, recuperando sua posição subjetiva e reconhecendo-se em seu próprio discurso. Ao criar sua própria versão de si, Amália poderá encontrar caminhos fora das amarras da cadeia da repetição que se encontrou em 26 anos vividos, podendo representar o que estava irrepresentável. Assumindo um papel de historiador, o sujeito poderá apropriar-se do passado e transformá-lo, criando novas âncoras no presente (Hornstein, 2008).

Para concluir, destaca-se uma citação de Kegler e Macedo (2016, para. 36) que contempla a potência transformadora da narrativa no espaço do processo analítico: "dar lugar à palavra é colocar o sujeito psíquico no lugar central de produtor das genuínas e autônomas condições de enfrentamento ao duro emudecimento gerado nas traumáticas experiências que escapam ao enlace do sentido".

\section{Considerações finais}

Trabalhar com a psicanálise é sempre estar trabalhando com o infantil, a partir da dinâmica inconsciente e, acima disso, é trabalhar com o desejo de sentido, de amor vindo do outro que chega buscando um espaço de escuta. Então, ao receber Amália, me vi frente a uma demanda de construção de si. Ela me concedeu uma passagem de ida aos seus primórdios, como um sujeito que pede um mapa para atravessar sua própria travessia. Travessia esta que não há um fim já posto, mas um fim no qual há de ser construído e sempre reatualizado ao percorrer os diversos entraves e desembaraços dessa jornada.

As primeiras relações do sujeito com o mundo que o entorna são demasiadamente significativas para criar um sentimento de si e, por consequência, disponibilizar recursos psíquicos que serão necessários para outras experiências de vida posteriormente. Quanto mais esse ambiente for envolto de amor, desejo e capacidade criativa dos objetos sobre o sujeito, mais apropriado de si e de sua história o indivíduo estará. E essa capacidade possibilitará ao sujeito, posteriormente, vir a amar alguém, isto é, ter relações em uma ordem de alteridade. São esses encontros com o outro diferente que fazem o devir de ser mais valioso, invocando a si o papel de eterno andarilho de sua própria travessia.

Entretanto, Amália encontra-se em um tempo anterior a essa possibilidade de ver-se como um eu íntegro. Sua vida não é comandada por si, mas sob intensidades que, devido ao (des)encontro traumático com seus objetos primordiais, não foram significadas. Ao ficar à mercê dessas pulsões tanáticas, estas tentam satisfazer-se através do ato - colocando Amália em relações que fazem perdurar a violação de seu existir e, consequente, seu sofrimento psíquico. Portanto, é com suas ferramentas mais potentes que a Psicanálise surge como uma possibilidade de rompimento dessa circulação mortífera que perpetua os modos de relação de Amália: com a escuta, com a palavra e com 0 sensível encontro que se sucede dentro do setting entre terapeuta e paciente.

Penso também que escrever um artigo baseado em um estudo de caso foi um desafio. Todos somos seres complexos e, ao estar trabalhando com a subjetividade humana, isso fica mais evidente. Logo, 0 ato de escrever um artigo faz com que seja necessária a eleição de pontos mais potentes dessa complexidade, para que estes possam ser trabalhados e, por consequência, gerar reflexões e debates à luz da teoria psicanalítica. Ao delimitar esses pontos, algo fica de fora, marcando então a condição de falta - tão conhecida e essencial no campo do desejo humano. Lidar com esta condição é sempre um desafio necessário e esse artigo pôs em vislumbre este.

\section{Referências}

Antoniazzi, S., \& Weinmann, A. O. (2018). O Filicídio na Teoria Psicanalítica e Seus (Des) Enlaces na Cultura Brasileira. Porto Alegre: Criação Humana.

Belo, F. (2004). Os efeitos da violência na constituição do sujeito psíquico. Psychê, 8(14), 77-94.

Birman, J., Fulgencio, L., Kupermann, D., \& Cunha, E. L. (2016). Amar a simesmo e amar o outro: narcisismo e sexualidade na psicanálise contemporânea. São Paulo: Zagodoni Editora LTDA.

Bleichmar, S. (1994). A Fundação do Inconsciente: destinos de pulsão, destinos do sujeito. Porto Alegre: Artes Médicas.

Bleichmar, S. (2005). Clínica Psicanalítica e Neogênese. São Paulo: Annablume. Cardoso, M. R. (2005). A servidão do "outro" nos estados limites. Psychê, $9(16), 65-75$.

Conte, B. S. (2002). Prazer e dor: o masoquismo e a sexualidade. Porto Alegre: Criação Humana.

Dockhorn, C. N. B. F., Macedo, M. M. K. \& Werlang, B. S. G. (2007). Desamparo e dor psíquica na escuta da psicanálise. Barbarói: Revista do Departamento de (iências Humanas, 1(27), 25-41.

Figueiredo, L. C. (2003). Psicanálise: elementos para a clínica contemporânea. São Paulo: Escuta.

Filho, F. C. S. (2011). Traumatismo psíquico - Realidade dos fatos, realidade psíquica e des(a)tino do sujeito (Tese de doutorado). Recuperado de https:// tede2.pucsp.br/bitstream/handle/14997/1/Francisco\%20Carlos\%20 dos\%20Santos\%20Filho.pdf

Freud, S. (1920/1977). Além do princípio de prazer. In J. Salomão (Org.), Além do princípio do prazer, psicologia de grupo e outros trabalhos (1920-1922) (pp. 12-85). Rio de Janeiro: Imago. 
Freud. S. (1937). A Técnica da Psicanálise. In J. Salomão (Org.), Moisés e o Monoteísmo, Esboço de Psicanálise e outros trabalhos (1937-1939) (pp.110-117). Rio de Janeiro: Imago.

Hornstein, L. (2008). As depressões: afetos e humores do viver. São Paulo: Via Lettera.

Kegler, P.\& Macedo, M. M. K. (2016). Narrativas do excesso: a potencialidade da palavra em psicanálise. Tempo psicanalitico, 48(1), 171-190.

Kehl, M. R. (2004). Ressentimento. São Paulo: Casa do Psicólogo.

Laplanche, J. \& Pontalis, J.B. (2016). Vocabulário da Psicanálise. São Paulo: Martins Fontes.

Lazzarini, E. R. \& Viana, T. C. (2010). Ressonâncias do narcisismo na clínica psicanalítica contemporânea. Análise Psicológica, 2(28), 269-280.

Macedo, M. M. K. (2015). Neurose: leituras psicanalíticas. Porto Alegre: ediPUCRS.

Mello, R. \& Herzog, R. (2012). Psiquismos clivados: vazio de sentido e insistência no existir. Cadernos de psicanálise (Rio de Janeiro), 34(27), 65-81.

Monteiro, R. R. G. \& Cardoso, M. R. (2016). A relação Eu/Outro nos estados limites: Aspectos teóricos e clínicos. SIG Revista de psicanálise, 1, 75-87.

Moraes, E. G. \& Macedo, M. M. K. (2011). Vivência de indiferença: do trauma ao ato-dor. São Paulo, SP: Casa do Psicólogo.

Santos, S. S. (2007). Algumas articulações entre narcisismo e estágio do espelho. Revista do (EP de PA - Centro de Estudos Psicanalíticos de Porto Alegre, 14, 49-61

Silva, P.V. (2008) 0 início do tratamento: da queixa à demanda - uma construção. In Escuta analítica: início de uma prática (pp. 37-44). Porto Alegre: Sigmund Freud Associação Psicanalítica.

Tizio, H. (2003) Ocorre que, às vezes, um rinoceronte nos refresca a memória. Opção Lacaniana, 35, 56-59. 